\title{
In Vitro Amelioration by Curcumin on Genotoxicity in Workers with Elevated Blood Cadmium Level
}

\author{
Ambar Pathan ${ }^{1}$, Ankit Nariya ${ }^{1}$, Naumita Shah ${ }^{1}$, Idrish Shaikh ${ }^{2}$, Jayesh Vyas ${ }^{2}$ and \\ Devendrasinh Jhala ${ }^{*}$ \\ ${ }^{1}$ Cell biology Lab., Department of Zoology, School of Sciences, Gujarat University, Ahmedabad-380 009, India. \\ ${ }^{2}$ National Institute of Occupational Health (Indian Council of Medical Research), Meghani Nagar, \\ Ahmedabad 380016, India.
}

\section{Abstract}

Curcumin is a dietary element, easily available and also well-known herb, for its therapeutic uses. On the other hand, cadmium is considered as an omnipresent, hazardous, heavy metal as well as known carcinogen, clastogen and mutagen. It is known to produce severe toxic effects during occupational exposure in industries related to nickelcadmium batteries, pigments, chemical stabilizers, metal coatings and alloys in humans. So, the objective of this study was to evaluate the ameliorative effects of curcumin as an antioxidant agent against cadmium induced genotoxicity in Peripheral Blood Lymphocyte Cultures (PBLC) of occupationally cadmium exposed individuals. The blood cadmium level was determined and it was significantly higher in exposed individuals as compared to controls. Blood samples from 40 workers exposed to cadmium, and 40 unexposed controls were used to analyse biochemical parameters like Total protein, GSH, GPx, GR, GST, LPO, CAT and SOD along with genotoxic parameters like SCEs, CCPI, AGT and PDT. The study revealed cadmium induced the free radicals formation which caused alteration in antioxidant defense system and may lead to genotoxicity. While curcumin ameliorates this toxicity by balancing the antioxidant defense system, decrease the lipid peroxidation and ultimately protect cells against cadmium genotoxicity. Hence, it can be concluded that curcumin which is herbal antidote can be helpful to protect cadmium toxicity in occupationally exposed workers.

Keywords: Cadmium, Curcumin, Free Radical Toxicity, Genotoxicity, PBLC

\section{Introduction}

Progressive industrialization in developing countries is currently evident and industrial revolution leads to increasing global metal pollution as well as increasing production and consumption of heavy metals including cadmium ${ }^{1}$. Cadmium is an extremely toxic element of continuing concern because environmental levels have risen steadily due to continued worldwide anthropogenic mobilization ${ }^{2}$. It is a widespread toxic pollutant of occupational and environmental concern because of its diverse toxic effects, long biological halflife (approximately 20-30 years in humans), low rate of excretion from the body and storage predominantly in soft tissues (primarily, liver and kidneys) ${ }^{1,3}$.

Exposure to cadmium can occur in all industry sectors but mostly in manufacturing and recycling including, $\mathrm{Ni}-\mathrm{Cd}$ batteries, plastics, coatings, and solar panels along with welding, painting, ship breaking, and landfill operations ${ }^{3}$. Besides the occupational exposure, human uptake of cadmium is mainly through cigarette smoking, food and water intake ${ }^{4}$. Cadmiumis known

\footnotetext{
${ }^{*}$ Author for correspondence

Email:ddjhala@gmail.com
} 
to cause cancer and targets the body's cardiovascular, renal, gastrointestinal, neurological, reproductive, and respiratory systems ${ }^{3}$. The molecular mechanisms of its toxicity are not yet well defined. Cadmium has been demonstrated to stimulate free radical production, resulting in oxidative deterioration of lipids, proteins and DNA, and initiating various pathological conditions in humans and animals. Moreover, a variety of accompanying changes in antioxidant defense enzymes were reported ${ }^{5}$.

Antioxidants are the natural defense mechanism existing in our system and these are capable of scavenging the deleterious free radicals. Attention has focused on the protective biochemical functions of naturally occurring antioxidants in biological systems against toxic heavy metals. Various modes and methodologies are being devised to combat cadmium-induced toxicity with a focus on herbal formulations ${ }^{6}$.

Curcumin, a yellow coloring ingredient of the spice turmeric (Curcuma longa Linn) obtained from the rhizome is a perennial herb used throughout the world. Curcumin represents a class of anti-inflammatory and antioxidants reported to be a potent inhibitor or scavenger of $\operatorname{ROS}^{7,8}$. Curcumin administration has been reported to prevent the arsenic, nickel, chromium, gentamicin and acetaminophen-induced oxidative stress and genotoxicity ${ }^{9-11}$. Based on the above information this study was designed to detect possible in vitro amelioration by curcumin against the toxicity of cadmium in occupationally exposed workers.

\section{Materials and Methods}

\subsection{Chemical Reagent}

All chemicals utilized in biochemical parameters were procured from Merck (AR Grade), while media and culture reagent were procured from HiMedia and Sigma Aldrich (Culture Grade).

\subsection{Sample Collection}

After obtaining human ethical committee approval, 10 $\mathrm{ml}$ of heparinized blood samples were collected from forty ship breaking yards workers of Alang, Gujarat, India, aged between 25-51 years with work exposure duration ranged from 2 to 25 years. Equal number of age and sex matched healthy nonsmoking donors with no history of knowingly exposure to any genotoxic agent were also selected as controls. Informed consent forms were filled and signed by each donor.

\subsection{Blood Cadmium Level (BCL) Determination}

Heparinized whole blood sample from both controls (40) and exposed (40) workers were digested using USEPA guidelines (Method - 30522) in Microwave digestion system (START-D, Milestone, Italy; USEPA, 1995). Blood Cadmium level was measured in triplicate with a background corrected atomic absorption spectrophotometer (Graphite Furnace Atomic Absorption Spectrophotometer, Perkin Elmer, USA) using the standard addition method at the Laboratory for Occupational Hygiene (NABL certified), National Institute of Occupational Health (NIOH), Ahmedabad, Gujarat.

Experimental design for cytogenetic study: The study was designed into various groups to evaluate the ameliorative effects of curcumin against cadmium toxicity in human peripheral blood lymphocytes culture as shown in Table 1.

Table 1: Experimental groups for cytogenetic study

\begin{tabular}{ll}
\hline Groups & Particulars \\
\hline Group I & Control (Con.) \\
Group II & Control + Curcumin (Con. + Cur.) $\left(3.87 \times 10^{-6} \mathrm{M}\right)$ \\
Group III & Exposed (Ex.) \\
Group IV & Exposed + Curcumin (Ex. + Cur.) $\left(3.87 \times 10^{-6} \mathrm{M}\right)$ \\
Group V & $\begin{array}{l}\text { Control + Ethyl Methanesulfonate (Con.+ EMS- } \\
\text { Positive control) }\left(1.93 \times 10^{-3} \mathrm{M}\right)\end{array}$ \\
\hline
\end{tabular}

For cytogenetic analysis, total 10 controls individuals' blood samples were selected and each sample was used for the PBLC of controls groups (Group I, II and V). Similarly, 10 exposed individuals' blood samples were selected and each exposed individuals' sample was utilized for the PBLC of exposed groups (Group III and IV).

\subsection{Cell Culture}

Peripheral blood lymphocytes were cultured and harvested according to the standard protocol of Hungerford $^{12}$. Lymphocyte cultures were set up by 
adding $0.5 \mathrm{ml}$ whole blood to $7 \mathrm{ml}$ of RPMI-1640 media supplemented with $7 \%$ heat-inactivated fetal calf serum along with $1 \%$ Streptomycin and Penicillin. Lymphocytes were stimulated by $100 \mu \mathrm{l}$ PHA $(1 \mathrm{mg} / 1$ $\mathrm{ml}$ d.w.) PHA and incubated for 72 hours at $37^{\circ} \mathrm{C}$. A final volume of $80 \mu \mathrm{l} \mathrm{BrdU}(1 \mathrm{mg} / 1 \mathrm{ml} \mathrm{d}$.w.) at $0 \mathrm{hr}$. was added along with the test compound (Curcumin and EMS). The cultures were gently mixed after every 24 hours to avoid clumping and to stabilize the $\mathrm{pH}$ of the media. At $69^{\text {th }}$ hours, $20 \mu \mathrm{l}$ colchicines $(1 \mathrm{mg} / 5 \mathrm{ml}$ d.w.) was added to the cultures to arrest cell division at metaphase stage. The cultures were harvested after $72 \mathrm{hr}$ of incubation by centrifugation at $2000 \mathrm{rpm}$ for $15 \mathrm{~min}$ and then supernatant was discarded and the pellet was treated with hypotonic solution for $15 \mathrm{~min}$ in $0.075 \mathrm{M}$ potassium chloride at $37^{\circ} \mathrm{C}$. After that cells were fixed in 1:3 (v/v) Acetic acid:Methanol solution. The fixation step was repeated twice. The resulting cells were resuspended in a 0.3 to $0.5 \mathrm{ml}$ of fixative and dropped onto clean slides.

The slides were then, differentially stained according to the Fluorescence-Plus-Giemsa (FPG) method of Perry and Wolff, $1974^{13}$ for scoring of metaphase plates (M1, M2 and M3- Figure 1) to analyze the sister chromatid exchanges (SCEs), Cell Cycle Proliferative Index (CCPI), Average Generation Time (AGT) and Population Doubling Time $(\mathrm{PDT})^{14}$.

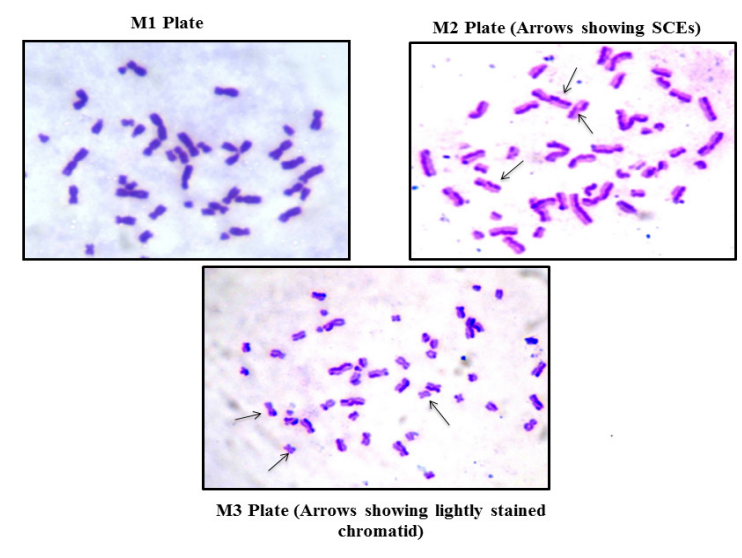

Fig. 1. Showing the M1, M2 with SCEs and M3 plate.

$$
\begin{aligned}
& \text { SCE } / \text { Cell }=\frac{\text { Total SCE scored }}{\text { Total M2 Metaphase Plates Observed }} \\
& \text { CCPI }=\frac{1(\text { M1 Plates })+2(\text { M2 Plates })+3(\text { M3 Plates })}{\text { Total Plates Scored }}
\end{aligned}
$$

AGT $($ Hour $)=\frac{72 \text { Hour }(\text { BrdU Time })}{\text { CCPI }}$

PDT $($ Hour $)=\frac{24 \text { Hour }}{\text { CCPI }}$

\subsection{In Vitro Analysis of Free Radical Toxicity in Plasma of Workers}

Blood plasma samples of controls (40) and exposed (40) workers were used for the assessment of various oxidative stress parameters such as Total protein, Lipid Peroxidation (LPO), Superoxide dismutase (SOD), Catalase (CAT), Total Glutathione (GSH), Glutathione S-Transferase (GST), Glutathione Peroxidase (GPx) and Glutathione Reductase (GR) using standard methods ${ }^{15-22}$.

\subsection{Statistical Analysis}

The results were expressed as Mean \pm S.E. The statistical significance was evaluated by Analysis of variance (ANOVA) using Graph Pad Prism 5 and the individual comparison were obtained by Tukey's multiple comparison tests and also by student's t-test. A value of $\mathrm{p}<0.05$ was considered to indicate significance difference.

\section{Results}

\subsection{Blood Cadmium Level (BCL)}

Blood cadmium levels from both controls and exposed workers were measured. The mean BCL of exposed workers $(35.0 \mu \mathrm{g} / \mathrm{l} \pm 0.002)$ showed highly significant $(\mathrm{p}<0.001)$ increase as compare to controls $(1.8 \mu \mathrm{g} / \mathrm{l} \pm$ $0.025)$.

\subsection{Cytogenetic Analysis}

\subsubsection{Sister Chromatid Exchanges (SCEs)}

The peripheral blood lymphocyte culture of exposed showed a slight increase in percent frequencies of sister chromatid $(\mathrm{P}<0.001$ for Group III) when compared to controls (Graph 1; Figure 2). Exposed cultures cosupplemented with Curcumin (Group IV) showed significant $(\mathrm{P}<0.01)$ amelioration as compared exposed group. (Group III).While the positive controls EMS (Group V) showed highly significant increase in SCEs 
as compared to controls in all studied parameters. The percent amelioration for SCEs with Curcumin (Group II) was $82 \%$ (Graph 1; Figure 2).

\subsubsection{SCEs/Cell}

The increase in SCEs/Cell of exposed culture showed highly significant $(\mathrm{P}<0.001$ for Group III) increase when compared to controls (Graph 2). Curcumin alone (Group II) did not show any alteration as compared to controls, where as its co-supplemented cultures along with exposed group revealed a significant $(\mathrm{P}<0.01$; Group IV) reduction in SCEs/Cell as compared to the exposed treated cultures (Group III). The percent amelioration for SCEs/Cell with Curcumin (Group IV) was $82 \%$ (Graph 2; Figure 2).

\subsubsection{Cell Cycle Proliferative Index (CCPI)}

Cell cycle proliferative index declined in the exposed cultures $(\mathrm{P}<0.01$; Graph 3$)$. Curcumin co-supplemented cultures with exposed group (Groups IV) showed highly significant recovery as compared to exposed culture (Group III). Exposed culture co-supplemented with Curcumin showed 76\% amelioration (Group IV; Figure 2).

\subsubsection{Average Generation Time (AGT) and Population Doubling Time (PDT)}

Exposed group (Group III,) showed highly significant increase $(\mathrm{P}<0.001)$ in AGT and PDT as compared to controls (Graph 4 and 5). Exposed individuals' cultures co-supplemented with Curcumin (Group IV) revealed significant decreased $(\mathrm{P}<0.01)$ in mean frequency of AGT and PDT when compared with exposed culture (Group III). Mitigation for both AGT and PDT with Curcumin was $79 \%$ and $80 \%$ respectively. Curcumin alone treated cultures (Group II) showed nonsignificant effect when compared to controls (Graph 4; Figure 2).

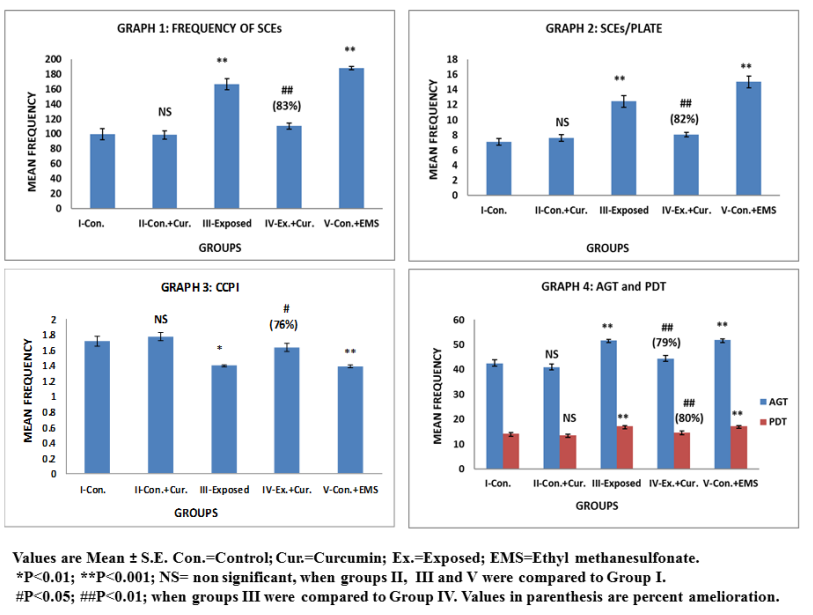

Fig. 2. Showing results of Cytogenetic parameters of various groups.

\subsection{Free Radical Toxicity Study}

A highly significant $(\mathrm{P}<0.001)$ decrease was observed in blood plasma protein and glutathione levels of workers (Group II) as compared to controls (Group I; Table 2). Superoxide dismutase is one of the key enzymes in defense against oxidative stress of cell. It showed straight depletion $(\mathrm{P}<0.001)$ in blood plasma of workers as compare to controls. Quantification of Thiobarbituric Acid Reactive Species (TBARS) was done as biochemical evidence for oxidative stress induced Lipid Peroxidation (LPO) along with free radical scavenging antioxidant enzyme activity. Highly significant $(\mathrm{P}<0.001)$ increase in LPO and decrease in free radical scavenging enzymes (CAT, GR, GST and GPx) activity was noted in blood plasma of workers (Group II) as compared to controls (Table 2).

Table 2: Free radical toxicity related parameters

\begin{tabular}{llllllllll}
\hline No. & Groups & $\begin{array}{l}\text { Total } \\
\text { protein }\end{array}$ & GSH & SOD & LPO & CAT & GR & GST & GPx \\
\hline I & Controls & $1.45 \pm 0.04$ & $1.66 \pm 0.06$ & $1.155 \pm 0.10$ & $3.976 \pm 0.43$ & $159.8 \pm 3.30$ & $62.24 \pm 6.65$ & $59.25 \pm 5.23$ & $1.134 \pm 0.05$ \\
II & Workers & $0.81 \pm 0.04^{*}$ & $1.05 \pm 0.06^{*}$ & $0.67 \pm 0.04^{*}$ & $8.60 \pm 0.63^{*}$ & $127.8 \pm 4.75^{*}$ & $42.53 \pm 0.65^{*}$ & $41.36 \pm 1.18^{*}$ & $0.38 \pm 0.06^{*}$ \\
\hline
\end{tabular}

Values are Mean \pm S.E; ${ }^{*} \mathrm{P}<0.001$. Total protein (Mean mg protein $/ 10^{6}$ Cells); GSH (Mean mM GSH/mg protein); SOD (Mean U SOD/mg protein); LPO (Mean nM MDA Formed/60 min/mg protein); CAT (Mean $\mathrm{nM} \mathrm{H}_{2} \mathrm{O}_{2}$ Consumed/min/mg protein); GR (Mean nM of NADPH Oxidised/min/mg protein); GST ( $\mu \mathrm{m}$ ofCDNB - GSH conjugates/min/mgprotein); GPx (Mean mM GSH Consumed/mg protein) 


\section{Discussion}

The present study evaluates the cytogenetic and biochemical assays in cadmium exposed workers. Numerous studies are available regarding cadmium induced oxidative stress in animals, but there is paucity of data regarding the oxidative stress analysis during occupational exposure, its correlation with cytogenetic damage if any and amelioration of adverse effects by herbal product. Hence, present study deals with the cadmium induce free radical toxicity, cytogenetic damage and the mitigating effects of curcumin on the Peripheral Blood Lymphocyte Culture (PBLC) of exposed individuals.

The ship breaking yard workers selected in the present studies showed high Blood Cadmium Level (BCL) may be due to exposure of polluted environment and inhalation of polluted air. The Occupational Health and Safety Administration (OSHA) ${ }^{23}$ has suggested that BCL in workers is hazardous at $>5 \mu \mathrm{g} / \mathrm{l}$. In this study, the mean BCL in cadmium exposed workers was very high $(35.0 \mu \mathrm{g} / \mathrm{l} \pm 0.002)$ as compared to controls $(1.8 \mu \mathrm{g} / \mathrm{l} \pm$ $0.025)$.

Cadmium could generate superoxide radical, hydroxyl radical and nitric oxide radicals indirectly ${ }^{24}$. A study by Watanabe and co-workers (2003) showed generation of hydrogen peroxide, which by itself became a significant source of free radicals ${ }^{25}$. To reduce these free radicals the major enzymatic antioxidants are Superoxide Dismutase (SOD), which degrades $\mathrm{O}_{2}$ - $^{-}$, catalase, GPx and the Glutathione (GSH) redox system, which inactivates $\mathrm{H}_{2} \mathrm{O}_{2}$ and hydroperoxides. GSH is also present extracellularly, have antioxidant capacity, and forms intermolecular disulphide oxidized glutathione (GSSG) which involved in detoxification of $\mathrm{H}_{2} \mathrm{O}_{2}{ }^{3,34}$. GSSG is either exported from the cell or converted to GSH by a reductase reaction with the help of GR and GST. On the other hand very high amount of free radical cause adverse effects on above cell defense system. So, in the present study free radical toxicity were estimated by enzymatic (SOD, catalase, GPx, GR, GST) and non-enzymatic (GSH, LPO, Protein) assays. We have observed a decrease in the activities of SOD, catalase, GPx, GR and GST in exposed individuals' blood plasma due to the generation of excessive amount of free radicals which leads to the production of oxidative stress by cadmium. Other studies also support the results obtained in present investigation ${ }^{2,9,26}$. This impairment of antioxidant defense mechanism may lead to an increase in membrane lipid peroxidation and decrease in GSH content as observed in this study.

Research provide clear evidence of the ability of cadmium to provoke indirect oxidative damage on the DNA, may lead to apoptotic mechanisms and blocking or inhibition of the DNA repair mechanisms ${ }^{27}$. Cadmium enters into cells through the voltagedependent $\mathrm{Ca}^{2+}$ channel and at the cellular level, it damages the DNA repair process in which the cellular redox status plays a crucial role ${ }^{28,29}$. In correlation with this, oxidative stress is assumed to be the principal molecular basis underlying cytotoxicity and cytogenetic damage caused by cadmium ${ }^{3}$. Hence, different genotoxic endpoints were assessed which also reflects the similar mechanisms of cadmium toxicity in the present findings. Sister Chromatid Exchange (SCE) analysis in human peripheral blood lymphocyte has often been applied as a cytogenetic testing of potentially mutagenic and carcinogenic chemicals ${ }^{30}$. An increased frequency of SCEs could be an indicator of persistent DNA damage ${ }^{31}$. In the present study also increase in the SCEs was found in exposed group which indicates the chromatin and DNA damage. Along with this, CCPI declined, AGT and PDT also got elongated which shows the alteration in the cell cycle and cell proliferation.

In contrast to the injurious activity of cadmium, curcumin serve as protective agent and it is the main ingredient of Indian curries ${ }^{32,33}$. In vitro and in vivo studies on animals have suggested a wide range of potential therapeutics or preventive effects associated with curcumin ${ }^{10,11,34,35}$. The antioxidant mechanism of curcumin is due to its specific conjugated structure of two methoxylated phenol and an enol form of $\beta$-Diketone. This structure is responsible for free radical trapping ability as a chain breaking antioxidant ${ }^{36}$. Several studies have demonstrated curcumin's ability to reduce oxidative stress $^{37-39}$. It is a stronger antioxidant and inhibitor of lipid peroxidation than other flavonoids, which have a single phenolic hydroxyl group ${ }^{40}$. It has been used as an antioxidant against toxicity of several metals including cadmium, copper, iron, lead and selenium ${ }^{41-45}$. In this study, also curcumin quenched the free radical and hence ameliorated the cadmium induced free radical dependent 
genotoxicity by balancing the antioxidant defense system. Our finding suggests that increased level of cadmium in blood may induce clastogenic effects in workers. Cadmium exposures can disturb antioxidant potential of the body, which is manifested by changes in the activity and/or concentration of antioxidant defense systems and leads to cytogenetic damage as found in our study. On the other hand, when curcumin was administered to the blood lymphocytes cell culture of workers, it ameliorated the cytogenetic damage significantly, may be by reducing the free radical toxicity. So, we conclude that curcumin, a cost efficient and easily available herb may serve as an efficient and physiologically potent antidote towards cadmium induced genotoxicity and free radical toxicity in occupationally exposed individuals.

\section{Acknowledgment}

This work is the part of a study supported by the University Grant Commission, New Delhi, in form of Maulana Azad National Fellowship.

\section{References}

1. Flora SJ, Mittal M, Mehta A. Heavy metal induced oxidative stress and its possible reversal by chelation therapy. Ind J Med Res. 2008; 128:501-23. PMid:19106443

2. Nair AR, DeGheselle O, Smeets K, Van Kerkhove E, Cuypers A. Cadmium-induced pathologies: Where is the oxidative balance lost (or not)? Inter J Mol Sci. 2013; 14:6116-43. https://doi.org/10.3390/ijms14036116PMid:23507750 PMCid:PMC3634456

3. Rani A, Anuj K, Ankita L, Manu P. Cellular mechanisms of cadmium-induced toxicity: a review. Inter J Environ Health Res. 2014; 24:378-99. https://doi.org/10.1080/096 03123.2013.835032 PMid:24117228

4. WHO (World Health Organization) Environmental Health Criteria 134 Cadmium International Programme on Chemical Safety (IPCS) Monograph; 2000.

5. Tezcan O, Pandır D, Bas H. The effects of cadmium on enzymatic antioxidant system and lipid peroxidation of human erythrocytes in vitro and the protective role of plasma level of vitamins C and E. Polish J Environ Stud. 2012; 21:1849-54.

6. Halliwell B, Gutteridge JM. Protection against oxidants in biological systems: the superoxide theory of oxygen toxicity In: Halliwell, Gutteridge, editors. Free Radical in Biology and Medicine Clarendon. Oxford, UK: Press; 1990. p. 86-123.

7. Biswas SK, McClure D, Jimenez LA, Megson IL, Rahman I. Curcumin induces glutathione biosynthesis and inhibits NFkappaB activation and interleukin-8 release in alveolar epithelial cells: mechanism of free radical scavenging activity. Antioxi Red Sig. 2005; 7:32-41. https://doi. org/10.1089/ars.2005.7.32 PMid:15650394

8. Eybl V, Kotyzova D, KoutenskyJ. Comparative study of natural antioxidants - curcumin, resveratrol and melatonin- in cadmium-induced oxidative damage in mice. Toxicol. 2006; 225:150-6. https://doi.org/10.1016/j.tox.2006.05.011 PMid:16806632

9. Fatma ME, Mokhtar IY, Fatma ME. Ameliorating effect of curcumin on sodium arsenite-induced oxidative damage and lipid peroxidation in different rat organs. Food Chem Toxicol. 2009; 47:249-54. https://doi.org/10.1016/j. fct.2008.11.013 PMid:19049818

10. Rao MV, Jhala DD, Chettiar SS, Patel AR. Evaluation of Curcumin as potential herbal agent for mitigation of nickel and chromium induced micronuclei in human blood cultures. Curr Tren Biotech Pharmacology. 2008a; 2:567-78.

11. Rao MV, Jhala DD, Patel A, Chettiar SS. Cytogenetic alteration induced by nickel and chromium in human blood cultures and its amelioration by Curcumin. Inter J Human Gen. 2008b; 8:301-5.

12. Hungerford DA. Leucocytes cultured from small inocula of whole blood and the preparation of metaphase chromosome by treatment with hypotonic potassium chloride. Stain Techn. 1965; 40:333-8. https://doi. org/10.3109/10520296509116440 PMid:5866557

13. Perry P, Wolf S. New Giemsa method for the differential staining of sister chromatids. Nature. 1974; 261:156-8. https://doi.org/10.1038/251156a0

14. Lamberti L, Bigatti PP, Ardito G. Cell kinetics and sister chromatid exchange frequency in human lymphocytes. Mutat Res. 1983; 120:193-9. https://doi.org/10.1016/01657992(83)90163-X

15. Lowry OH, Rosenbrough NJ, Farr AL, Randall RJ. Protein measurement with the folin phenol reagent. J Bio Chem. 1951; 193:265-75.

16. Ohkawa H, Ohishi N, Yagi K. Assay for lipid peroxides in animal tissue by thiobarbituric acid reaction. Analy Biochem. 1979; 95:351-8. https://doi.org/10.1016/00032697(79)90738-3 
17. Kakkar P, Das B, Viswanathan PN. A modified spectrophotometric assay of superoxide dismutase. Ind J Biochem Biophys. 1984; 4130-2.

18. Sinha AK. Colorimetric assay of catalase. Analy Biochem. 1972; 47:389-94. https://doi.org/10.1016/00032697(72)90132-7

19. Ellman GL. Tissue sulfhydryl groups. Arch Biochem Biophys. 1959; 82:70-7. https://doi.org/10.1016/00039861(59)90090-6

20. Habig WH, Pubst MJ, Jokoby. GST, the first enzyme step in mercaptune acid formation. J Bio Chem. 1974; 249:71309.

21. Rotruck JT, Pope AL, Ganther HE, Swason AB, Hafeman DG, Hoekstra WG. Selenium: Biochemical role as a component of glutathione peroxidase. Sci. 1973; 179:58890. https://doi.org/10.1126/science.179.4073.588

22. Carlberg I, Mannervik B. Glutathione reductase. Metho Enzym. 1985; 113:485-90. https://doi.org/10.1016/S00766879(85)13062-4

23. OSHA (Occupational Safety and Health Association). Safety and Health Topics Cadmium. Washington, DC: US Department of Labour Occupational Safety and Health Administration OSHA 3136-06R; 2008. Available from: http://wwwoshagov/Publications/osha3136pdf

24. Galan A, Garcia-Bermejo L, Troyano A, Vilaboa NE, Fernández C, de Blas E Aller P. The role of intracellular oxidation in death induction (apoptosis and necrosis) in human promonocytic cells treated with stress inducers (cadmium, heat, X-rays). Eur J Cell Bio. 2001; 80:312-20. https://doi.org/10.1078/0171-9335-00159 PMid:11370746

25. Watanabe M, Henmi K, Ogawa K, Suzuki T. Cadmiumdependent generation of reactive oxygen species and mitochondrial DNA breaks in photosynthetic and non-photosynthetic strains of Euglena gracilis. Compara Biochem Physio/Compara Toxicol Pharmacol. 2003; 134:227-34. https://doi.org/10.1016/S15320456(02)00253-3

26. Ogunrinola OO, Wusu DA, Fajana OO, Olaitan SN, Smith $\mathrm{ZO}$, Bolaji AR. Effect of low level cadmium exposure on superoxide dismutase activity in rat. Tropi J Pharma Research. 2016; 15:115-9. https://doi.org/10.4314/tjpr. v15i1.16

27. Aimola $\mathrm{P}$, Carmignani $\mathrm{M}$, Volpe AR, Di Benedetto Claudio L, Waalkes MP, Bokhoven A, et al. Cadmium induces p53-dependent apoptosis in human prostate epithelial cells. PLoS ONE. 2012; 7: e33647 https:// doi.org/10.1371/journal.pone.0033647PMid:22448262 PMCid:PMC3308998
28. Li M, Kondo T, Zhao QL, Li FJ, Tanabe K, Arai Y, et al. Apoptosis induced by cadmium in human lymphoma U937 Cells through Ca21-calpain and caspase-mitochondria dependent pathways. J Bio Chem. 2000; 275:39702-9. https://doi.org/10.1074/jbc.M007369200 PMid:10970901

29. Cuypers A, Plusquin M, Remans T, Jozefczak M, Keunen E, Gielen H, et al. Cadmium stress: an oxidative challenge. Biometals. 2010; 23:927-40. https://doi.org/10.1007/ s10534-010-9329-x PMid:20361350

30. Natarajan AT. Chromosome aberrations: Past, present and future. Mutat Res. 2002; 504:3-16. https://doi.org/10.1016/ S0027-5107(02)00075-1

31. Cardoso RS, Takahashi-Hyodo S, Peitl P, Ghilardi-Neto JT, Sakamoto-Hojo ET. Evaluation of chromosomal aberrations, micronuclei and sister chromatid exchange in hospital workers chronically exposed to ionizing radiation. Terato Carci Mutat. 2001; 21:431-439. https:// doi.org/10.1002/tcm.1030 PMid:11746256

32. Aggarwal BB, Kumar A, Bharti AC. Anticancer potential of Curcumin: preclinical and clinical studies. J Antican Res. 2003; 23:363-98.

33. Aggarwal BB, Sundaram C, Malani N, Ichikawa $H$. Curcumin: The Indian solid gold in the molecular targets and therapeutic uses of curcumin in health and disease. Springer US. 200; 1-75.

34. Giri AK, Sharma A, Talukder G. Relative efficancy of short term test in detecting genotoxic effects of cadmium chloride in mice in vivo. Mutat Res. 1988; 206:285-95. https://doi.org/10.1016/0165-1218(88)90173-5

35. Singh P, Sankhla V. In situ protective effect of curcumin on Cadmium chloride induced genotoxocity in bone marrow chromosome of Swiss albino mice. J Cell Mol Bio. 2010; 8:57-64.

36. Masuda T, Maekawa T, Hidaka K. Chemical studies on antioxidant mechanism of Curcumin: Analysis of oxidative coupling product from Curcumin and linoleate. J Agri Food Chem. 2001; 49:2539-47. https://doi.org/10.1021/ jf001442x

37. Iqbal M, Sharma S, Okazaki Y, Fujisawala MO. Dietary supplementation of Curcumin enchances antioxidant and phase II metaboli 3 zing enzyme in ddY male mice: Possible role in protection against chemical carcinogenesis and toxicity. Pharmacol Toxicol. 2003; 92:33-8. https://doi. org/10.1034/j.1600-0773.2003.920106.x PMid:12710595

38. Tarasub N, Thongbai J, Chinnawat T, Watcharaporn D. Protective effects of Curcumin and Vitamin C, or their combination on Cadmium induced Hepatotoxicity. 
J Basic Clin Pharmacol. 2012; 3:273-9. https://doi. org/10.4103/0976-0105.103821

39. Atef M, Attia M, Fatma A, Ibrahim A, Noha A, Abd EL-Latif, et al. Antioxidant effects of curcumin against cadmium chloride-induced oxidative stress in the blood of rats. J Pharmacol Phyto. 2015; 6:33-40.

40. Phan TT, See P, Lee ST, Chan SY. Protective effects of curcumin against oxidative damage on skin cells in vitro: its implication for wound healing. J Trauma. 2001; 51:927-31. https://doi.org/10.1097/00005373-20011100000017 PMid:11706342

41. Daniel S, Limson JL, Dairam A, Watkins GM, Daya S. Through metal binding, curcumin protects against lead and cadmium induced lipid peroxidation in rat brain homogenates and against lead-induced tissue damage in rat brain. Inorg Chem. 2004; 98:266-75. https://doi. org/10.1016/j.jinorgbio.2003.10.014

42. Nair J, Strand S, Frank N, Knauft J, Wesch H, Galle PR, et al. Apoptosis and age- dependant induction of nuclear and mitochondrial etheno-DNA adducts in Long-Evans Cinnamon (LEC) rat enhanced DNA damage by dietary curcumin upon copper accumulation. Carcinogen. 2005; 26:1307-15. https://doi.org/10.1093/carcin/bgi073 PMid:15790590

43. Manjunatha $\mathrm{H}$, Srinivasan K. Protective effect of dietary curcumin and capsaicin on induced oxidation of lowdensity lipoprotein, iron-induced hepatotoxicity and carrageenan-induced inflammation in experimental rats. FEBS J. 2006; 273:4528-37. https://doi.org/10.1111/ j.1742-4658.2006.05458.x PMid:16956363

44. Dairam A, Limson JL, Watkins GM, Antunes E, Daya S: Curcuminoids, curcumin and demethoxycurcumin reduce lead-induced memory deficits in male Wistar rats. J Agri Food Chem. 2007; 55:1039-44. https://doi. org/10.1021/jf063446t PMid:17263510

45. Padmaja S, Raju TN. Antioxidant effect of curcumin in selenium induced cataract of Wistar rats. Ind J Exp Biol. 2004; 42:601-3. PMid:15260112 